\title{
THE CHALLENGES OF ACHIEVING SMART, SUSTAINABLE AND INCLUSIVE GROWTH IN BULGARIA
}

\author{
Christo Ivanov ${ }^{1}$ (i)
}

DOI: https://doi.org/10.31410/LIMEN.S.P.2019.135

\begin{abstract}
In the early 21 st Century, when the Lisbon Strategy is passed, strategic planning in Europe experiences dynamic development. A new strategic document titled Europe 2020 is passed in 2010. Its goal is to make the European Union smart, sustainable and inclusive economy delivering high levels of employment, productivity and social cohesion. The document has outlined eight measurable headline targets. Following its entry into the EU in 2007, Bulgaria is also expected to fulfil the requirements of the Europe 2020 strategy and achieve the specific targets that have been set. The main purpose of the paper is to identify Bulgaria's progress towards achieving the targets set at European level, and to outline the primary problems the country faces in the process of achieving said targets. The main conclusion is that despite its progress regarding some of the headline targets, Bulgaria has yet to achieve smart, sustainable and inclusive growth.
\end{abstract}

Keywords: Headline targets, Strategy implementation, European Union.

\section{INTRODUCTION}

$\mathrm{T}$ he development of strategic planning is given a strong push in the late $20^{\text {th }}$ Century, when leaders of the EU's member states ascertain the fact that European economy is showing an increasingly noticeable lag, compared to its main competitors on the global stage. In order to overcome these lags, in March 2000, the Lisbon European Council passes the Strategy for Economic and Social Renovation of Europe (The Lisbon Strategy). The main objective of the document is for the European Union to become the most competitive and dynamic, knowledge-based, economy in the world, capable of stable economic development with more and better jobs, and larger social cohesion (European Parliament, 2000).

In spite of the set main objective in the Lisbon Strategy, as of 2010 „,comparing the EU27 with a selected group of major global competitors shows that the US, Japan and South Korea have a performance lead over the EU27" (Innovation Union Scoreboard 2011, 2012, p.9). Moreover, the distance in development with countries such as China and India is gradually shortening. Similar conclusions can be made for labor markets where „relative to comparable advanced economies, many European countries exhibit low rates of employment and high rates of unemployment" (Baldwin, Wyplosz, 2012, p.233). In a report entitled Facing the challenge ,the weak links between the Lisbon Strategy and the other EU strategies or tools, lack of commitment and political will, necessity of more coherence consistency in implementation, lack of engagement of national governments and citizens in implementation, necessity for vigorous communications" (High Level Group, 2004, p.39) are cited as reasons for the failure of the Lisbon Strategy.

In order to achieve the desired future development, the Europe 2020 Strategy for Intelligent, Stable and Inclusive Growth is passed on March 3 2010. Eight measurable headline targets have been outlined to measure the EU's progress along the road to achieving the strategy's priorities.

University of National and World Economy, Sofia, Bulgaria, address: 1700 Sofia, Student Town, UNWE 
To ensure that each Member State tailors the Europe 2020 strategy to its particular situation, the EU goals are translated into national targets. The headline targets are focusing on: employment, the size of expenses for research and development (R\&D), greenhouse gas emissions, share of renewable energy sources in final energy consumption, energy efficiency, early school leavers, reached levels of tertiary education, people who live below the national poverty lines.

One of the major criticisms aimed at the Lisbon strategy is that the „EU-level targets were too numerous and did not sufficiently reflect differences in starting positions between the Member States" (European Commission, 2010, p.6). The introduction of the eight headline targets at the starting point gives the possibility for the leaders and policymakers of the European Union to keep track and analyse the transition of the Union as a whole and the member states towards achieving smart, sustainable and inclusive growth. This is considered as an attempt to overcome the above-mentioned criticism.

\section{RESULTS OF THE IMPLEMENTATION OF THE EUROPE 2020 STRATEGY IN BULGARIA}

Following its accession into the EU in 2007, Bulgaria is also expected to fulfill the requirements of the Europe 2020 strategy and achieve the specific goals outlined in it. At present, the country has managed to cover three of the eight headline targets of the Europe 2020 strategy, whereas most of the other targets show tendencies of improvement in the values of indicators. Education holds a significant position in the strategy, with two headline targets outlined for it. The first target involves early leavers from education and training, calculated as a percentage of the population aged 18-24, which should be lower than $11 \%$ in Bulgaria. This is among the headline targets that have not shown improvement. According to the data from Eurostat (2019) in 2010 the indicator's value is $12,6 \%$, growing to $12,7 \%$ in 2017 . Moreover, the $2011-2016$ period shows a tendency of constant growth for the indicator's values. In addition to that since 2013 Bulgaria has worst percentage for the early school leavers in comparison with the European Union as a whole. At the end of 2017 fourteen countries managed to achieve their set national target.

The second headline target in the field of education involves the percentage of the population aged 30-34 who have successfully completed tertiary studies. In accordance with what is outlined, this share should reach 36\% in Bulgaria. During the 2010-2017 period the share of tertiary education graduates has risen from $28 \%$ to $32,8 \%$. Despite the clear positive trend observed in the indicator's values, several negative facts are present. In 2017 there are just four countries with lower level of tertiary educational attainment for the age group 30-34 years. They are Hungary $32,1 \%$, Croatia $28,7 \%$, Italy $26,9 \%$ and Romania $26,3 \%$. In addition to that in 2017 fifteen countries have already reached their national targets concerning tertiary education.

According to the data from QS World University Rankings (2019), no Bulgarian universities have managed to rank among the top universities in the world. When it comes to discussing education, the most important question concerns quality. Drucker states that ,in most knowledge work, quality is not a minimum and a restraint. Quality is the essence of the output" (Drucker, 1999, p. 143). In this field it is appropriate to judge the quality of education not by the number of graduated students but by the number of students who emerge on the labor market and possess knowledge and skills that fulfil the requirements of knowledge economy. At this stage, Bulgaria has yet to make the necessary transition from quantity to quality. 
Table 1. Implementation of Bulgarian headline targets

for Europe 2020 strategy (2010-2017 period)

\begin{tabular}{|l|c|c|c|c|c|c|c|c|c|}
\hline Headline targets & $\mathbf{2 0 1 0}$ & $\mathbf{2 0 1 1}$ & $\mathbf{2 0 1 2}$ & $\mathbf{2 0 1 3}$ & $\mathbf{2 0 1 4}$ & $\mathbf{2 0 1 5}$ & $\mathbf{2 0 1 6}$ & $\mathbf{2 0 1 7}$ & Target \\
\hline $\begin{array}{l}\text { Employment rate, age group } \\
\mathbf{2 0 - 6 4} \%\end{array}$ & 64.7 & 62.9 & 63.0 & 63.5 & 65.1 & 67.1 & 67.7 & 71.3 & 76.0 \\
\hline $\begin{array}{l}\text { Gross domestic expenditure on } \\
\text { R\&D, \% of GDP }\end{array}$ & 0.56 & 0.53 & 0.60 & 0.64 & 0.79 & 0.96 & 0.78 & 0.75 & 1.50 \\
\hline $\begin{array}{l}\text { Greenhouse gas emissions, base } \\
\text { year 1990 }\end{array}$ & 59.53 & 64.70 & 59.74 & 54.59 & 57.56 & 60.68 & 58.23 & 60.53 & 80.00 \\
\hline $\begin{array}{l}\text { Share of renewable energy in } \\
\text { gross final energy consumption, } \\
\text { \% }\end{array}$ & 14.07 & 14.29 & 16.05 & 18.95 & 18.04 & 18.21 & 18.81 & 18.73 & 16.00 \\
\hline $\begin{array}{l}\text { Primary energy consumption, } \\
\text { Million TOE }\end{array}$ & 17.41 & 18.58 & 17.86 & 16.50 & 17.27 & 17.97 & 17.68 & 18.33 & 16.90 \\
\hline $\begin{array}{l}\text { Early leavers from education } \\
\text { and training, \% of the } \\
\text { population aged 18-24 }\end{array}$ & 12.60 & 11.80 & 12.50 & 12.50 & 12.90 & 13.40 & 13.80 & 12.70 & 11.00 \\
\hline $\begin{array}{l}\text { Tertiary educational } \\
\text { attainment, age group 30-34 }\end{array}$ & 28.0 & 27.3 & 26.9 & 29.4 & 30.9 & 32.1 & 33.8 & 32.8 & 36.0 \\
\hline $\begin{array}{l}\text { People of risk of poverty or } \\
\text { social exclusion, Cumulative } \\
\text { difference from 2008, in } \\
\text { thousands }\end{array}$ & 298 & 272 & 200 & 72 & -512 & -439 & -531 & -654 & -260 \\
\hline
\end{tabular}

Source: Eurostat

Another headline target in the strategy concerns R\&D. In accordance with what is outlined, R\&D expenditures in Bulgaria should make up 1,5\% of the gross domestic product (GDP) by 2020. At first glance, there seems to be a positive trend when it comes to the indicator's values. In $2010 \mathrm{R} \& \mathrm{D}$ costs in Bulgaria are $0,56 \%$, reaching $0,75 \%$ in 2017 . The data makes it clear that at this stage Bulgaria is still a long way from reaching the set target, which is unlikely to happen if the current trends remain unchanged. Moreover, the indicator's values have been declining over the past three years - in 2015 R\&D costs make up $0,96 \%$ of the GDP, dropping to $0,78 \%$ in 2016 , and finally reaching $0,75 \%$ in 2017. In addition to the above-mentioned facts, there are only four countries in European Union which in 2017 have low level of gross domestic expenditure on research and development as a percent of GDP. They are Cyprus with $0.56 \%$, Malta $0.54 \%$, Latvia $0.51 \%$ and Romania $0.50 \%$.

In terms of headline targets, the issue of environmental protection is the most strongly advocated one in the Europe 2020 strategy, with three of the aforementioned targets dedicated to it. According to what is outlined in the strategy, greenhouse gas emissions should be $80 \%$ in comparison to emissions in 1990, which is one of the three headline targets that Bulgaria has so far managed to reach. By 2017 greenhouse gas emissions are 60,53\% compared to emissions in 1990. In terms of this indicator, Bulgaria ranks sixth in the EU, only falling behind Lithuania, Latvia, Romania, Estonia and Slovakia. Although the set target has been reached, no serious progress has been recorded for greenhouse gas emissions since the strategy's realization was put into motion, which is substantiated by the fact that in 2010 the indicator reads a value of $59,53 \%$, meaning that the studied period shows a rise in greenhouse gas emissions. The achievement of the set goal in Bulgaria is due in no small part to the decline of industrial production, observed in the years following the transition toward market economy.

Another headline target dedicated to environmental protection requires that Bulgaria's share of renewable energy in final energy consumption reach $16 \%$. Said goal is achieved in 2012, with the indi- 
cator's values currently reaching $18,73 \%$. Only Croatia, Estonia and Hungary have managed to fulfil the aforementioned requirements regarding renewable energy in final energy consumption faster than Bulgaria. Investments in renewable energy sources made immediately after 2010 with the purpose of quickly reaching this headline target also bring about some unfavorable consequences.

The first one is related with the fact that the prices of solar technologies are constantly falling during the second decade of XXI century. In a report entitled Renewable power generation costs in 2018 is written that ,the global weighted-average levelised cost of electricity of the newer solar and wind power technologies - concentrating solar power, utility-scale solar photovoltaics, onshore and offshore wind have all fallen between 2010 and 2018" (IRENA, 2019, p. 11). The significant investments in Bulgaria made immediately after 2010 led to drastic rise in electric energy prices for households and industry alike as a result of the higher prices of the solar technologies at that time. This resulted in social discontent aimed at the country's government.

The second unfavorable consequence results from the fact that over time technology involving renewable energy develops and becomes more effective. According to the report entitled Future of solar photovoltaic ,the evolution of the solar PV industry so far has been remarkable, with several milestones achieved in recent years in terms of installations (including off-grid), cost reductions and technological advancements" (IRENA, 2019, p. 19). The constant improvement in the renewable energy technology could mean that at the end of the period for the realization of the Europe 2020 strategy Bulgaria will have achieved the goal, but at the cost of obsolete technology purchased at high prices.

The third headline target in the field of environmental protection requires that primary energy consumption in Bulgaria be lower than 16,9 million tons of oil equivalent (MTOE). In terms of this goal, there has been a decline in results. In 2010, primary energy consumption in Bulgaria is 17,41 MTOE, reaching 18,33 MTOE in 2017. For the 2010-2017 period Bulgaria is one of the six countries which have declined in results. In 2017 twelve countries have so far managed to reach the target.

On European level, there are positive trends in the achievement of the headline targets concerning environmental protection. The European Union has already made significant progress over the past decade not only in terms of climate change mitigation and reducing greenhouse gas emissions but also in other areas, such as tackling water pollution and reducing the plastic waste. Despite the positive trends in environmental protection, the European Union has been criticized multiple times for not setting higher goals for itself when it comes to climate. The European environment state and outlook 2020 report states that „despite the success of EU environmental policies, the outlook for Europe's environment is discouraging" (European Environment Agency, 2019, p.11). In the report is also written that against Europe's long-term vision and complementary policy targets, it is clear that Europe is not making enough progress in addressing environmental challenges.

The necessity for more ambitious goals is also confirmed by the Paris Agreement regarding climate change. As a result of the Paris Agreement, the European Union sets the following targets which are to be achieved by 2030: at least $40 \%$ reduction of greenhouse gas emissions compared to levels from 1990; at least 32\% share of renewable energy in final energy consumption; improving energy efficiency by $32.5 \%$. Additionally, in order to keep global warming under 1.5 degrees (the target set by the UN) the European Commission presented its vision for prosperous, modern, competitive and climate-neutral economy by 2050 . 
The European 2030 headline targets are twice as demanding as the current national targets for Bulgaria. The European push to speed up actions to put European Union on track to meet its medium and long-term environmental policy goals and targets will urge Bulgarian leaders and policymakers to stimulate significant additional investments for achieving sustainable development of the country.

The final two headline targets in the Europe 2020 strategy concern employment and risk of poverty. In accordance with what is outlined, the employment rate among people in the 20-64 age group in Bulgaria should reach $76 \%$. In terms of this goal, the indicator's values have shown a positive trend of growing. In 2010 the level of employment in Bulgaria is 64,7\%, reaching 71,3\% in 2017. However, despite the country's efforts to increase the level of employment, the indicator's value is still far from reaching the one set in the strategy. Although the national target for Bulgaria is higher than the target for the European Union as a whole (75\%), for the entire period 2010-2017 the indicator's value in the Union is higher than the value for Bulgaria. Additionally, in some cases employment is stimulated purely for employment's sake. Bulgaria needs to make a transition toward stimulating employment that will result in accomplishing the goals of the Europe 2020 strategy - namely, achieving intelligent, stable and inclusive growth.

The final headline target of the Europe 2020 strategy requires that the population in risk of poverty or social exclusion be reduced by 260000 people, as a cumulative difference from 2008, which is the third headline target which is achieved in Bulgaria. In 2017, the population in risk of poverty or social exclusion has dropped by 654000 people. Tanushev states that ,at the time of its admission to the EU Bulgaria was permanently the poorest country in the community" (Tanushev, 2012, p. 15). Despite the decrease of the population in risk of poverty or social exclusion Bulgaria is still presented as the poorest country in the EU.

Figure 1. Gross domestic product per capita in purchasing power standards for 2017, index $(\mathrm{EU} 28=100)$

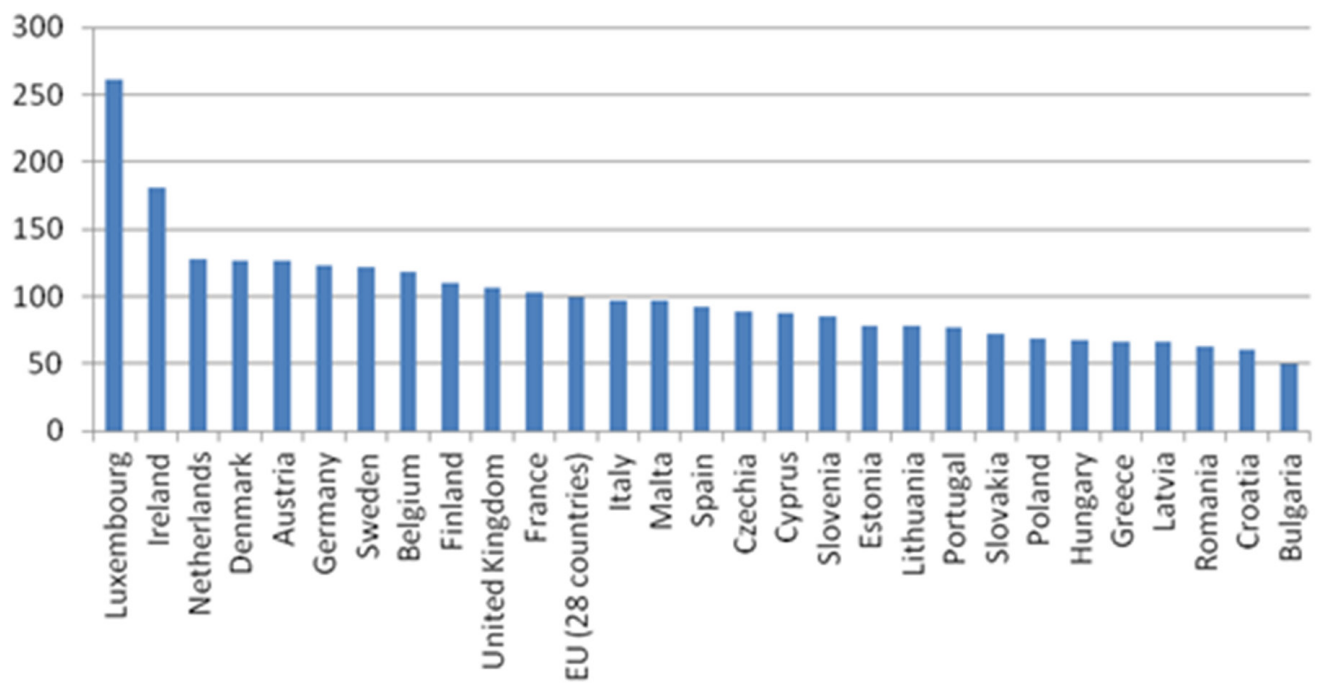

Source: Eurostat

In 2017, Bulgaria is the last country in European Union concerning the indicator gross domestic product (GDP) per capita in purchasing power standards. In addition to that, the value of the indicator is half as much as the average for the European Union as a whole. In relation to GDP 
per capita Bulgaria is far behind the newest member of the European Union - Croatia and far behind the country with which became a full member of the European Union - Romania. In order to overcome the fact that the country is still the poorest country in the Union, systematic efforts will have to be made to improve living standards for the population in Bulgaria.

\section{CONCLUSION}

With the adoption of the Europe 2020 strategy, Bulgaria has begun the process of achieving the national goals outlined in it. At present, the country has managed to cover three of the eight headline targets of the Europe 2020 strategy. They are related with the level of greenhouse gas emissions, the share of renewable energy in gross final energy consumption and the people at risk of poverty or social exclusion. Three of the other targets have shown tendencies of improvement regarding the values of indicators: employment rate in age group 20-64 years, gross domestic expenditure on R\&D and tertiary educational attainment for age group 30-34.

Despite the overall indicated positive trends, there are a number of negative inferences. There are headline targets which show no advancement towards the desired state, i.e. early leavers from education and training and primary energy consumption. The European policy regarding environment protection will exert higher pressure on Bulgarian economy in the future which will demand significant additional investments for achieving sustainable development of the country. Despite the achievement of the headline target concerning decrease in the number of populations in risk of poverty or social exclusion, Bulgaria can still be presented as the poorest member of the European Union. Efforts which involve improving the quality of higher education, stimulating R\&D, creating stable jobs and improving the population's living standards are still insufficient on a national level. The main conclusion of the paper is that despite its progress regarding some of the headline targets, Bulgaria has yet to achieve smart, sustainable and inclusive growth.

\section{REFERENCES}

Baldwin, R., \& Wyplosz, C. (2012). The Economics of European Integration, fourth edition, UK: McGraw-Hill Education

Drucker, P. (1999). Management Challenges for $21^{\text {st }}$ Century, New York: Harper Business.

European Commission. (2010). Lisbon strategy evaluation document, [online] Available at: https://ec.europa.eu/transparency/regdoc/rep/2/2010/EN/SEC-2010-114-F1-EN-MAINPART-1.PDF

European Environment Agency. (2019). The European environment - state and outlook 2020 Knowledge for transition to a sustainable Europe, Luxembourg: Publications Office of the European Union, doi: 10.2800/96749

European Parliament. (2000). Lisbon European Council 23 and 24 March 2000 Presidency Conclusions [online] Available at: http://www.europarl.europa.eu/summits/lis1_en.htm

Eurostat. (2019). Europe 2020 indicators, [online] Available at: https://ec.europa.eu/eurostat/ web/europe-2020-indicators/europe-2020-strategy/main-tables

High Level Group chaired by Wim Kok. (2004). Facing the challenge - The Lisbon strategy for growth and employment [online] Available at: http://ec.europa.eu/research/evaluations/ pdf/archive/fp6-evidence-base/evaluation_studies_and_reports/evaluation_studies_and_ reports_2004/the_lisbon_strategy_for_growth_and_employment_report_from_the high_level_group.pdf 
Innovation Union Scoreboard 2011. (2012). European Union, [online] Available at: https://ec.europa.eu/eip/ageing/library/innovation-union-scoreboard-2011_en, ISBN 978-92-79-231742, doi:10.2769/32530

IRENA. (2019). Future of Solar Photovoltaic: Deployment, investment, technology, grid integration and socio-economic aspects (A Global Energy Transformation: paper), International Renewable Energy Agency, Abu Dhabi, ISBN: 978-92-9260-156-0

IRENA. (2019). Renewable Power Generation Costs In 2018, International Renewable Energy Agency, Abu Dhabi, ISBN: 978-92-9260-126-3

QS World University Rankings, 2019. University rankings [online] Available at: https://www. topuniversities.com/university-rankings/world-university-rankings/2020

Tanushev, C. (2012). Economic Growth and EU Funds in Bulgaria (2007-2011). Paper presented at International Scientific Conference Serbia and the European Union, Nish, Serbia, 2012, Proceedings, pp. 15-30, ISBN: 978-86-6139-061-6 